\title{
The Co-evolution of Business Incubators and National Incubator Networks in Emerging Markets
}

\author{
David F. Robinson'
}

\begin{abstract}
The study proposes a three stage model of the development of business incubation practices in emerging markets. The model addresses the diffusion of incubation practices to new markets, the institutionalization of those practices and the co-evolution of incubators and national networks of incubation. The model is based on interviews conducted in Bolivia, Peru, Chile, Argentina, and Brazil. New incubators in emerging markets often face strong cultural norms and institutional impediments to helping entrepreneurs start new businesses. As incubation becomes better established in a country, incubators provide more advanced technical, legal and market-based advice. Networks of incubators form to share specialized services across many incubators, to allocate government funding to incubators, and to lobby for public and private support of innovation.
\end{abstract}

Keywords: business incubation; co-evolution; institutional theory; innovation; networks; development; South America.

\footnotetext{
I Scott College of Business. Indiana State University. 800 Sycamore St. Terre Haute, IN 47809. USA. Tel.: 00I-8I 2-237-8829. Email: david.robinson@indstate.edu
} 


\section{Introduction}

Business incubation encourages new business formation and offers the potential to improve emerging market economies by improving survival rates and growth of new businesses. A business incubator is defined as "A business incubator is a shared office space facility that seeks to provide its incubatees with a strategic or valueadding intervention system of monitoring and business assistance." (Hackett and Dilts, 2004, p. 57). Incubators originated as a means to recycle surplus buildings into new businesses in order to improve economic development (Hackett and Dilts, 2004). Incubators improve entrepreneurs access to services, decrease the start-up costs for new firms, and improve their access to markets (iDisc, 2003). Worldwide, there are over 4,000 incubators (Hackett and Dilts, 2004).

Although business incubation practices originated in developed economies, incubation is now practiced in many emerging markets. Cultural and political conditions cause variation in the incubation infrastructure and focus. By understanding the development of incubators in emerging markets, incubator managers, policy makers and entrepreneurs can better anticipate the forces that will shape their development efforts.

I propose a three stage model for the development of business incubation practices in emerging markets. A key feature of the model is the co-evolution of the incubators' capabilities and the creation and elaboration of national networks of incubation. The five countries studied (Argentina, Bolivia, Brazil, Chile and Peru) have created business incubators to encourage and advise entrepreneurs how to start new businesses and to improve the likelihood that these businesses will survive. Non-governmental organizations (NGOs), universities, government economic development agencies and private foundations encourage incubator formation by providing know-how, managerial talent, advising and financial support.

New incubators in emerging markets often face strong cultural norms that impede entrepreneurs from starting businesses. They also face structural impediments from institutions operating in the economy. Incubators provide technical, legal and market-based advice. Incubators assist entrepreneurs to establish relationships with suppliers and customers through contacts through the incubator's organizational networks. Basic business incubation practices are common across almost all incubators but specialized practices (intellectual property protection, engineering design) are unique to specific incubators. The development of incubator networks varies significantly across the five countries studied.

Most incubators in this study offered their clients space for rent, access to trained business counselors, and assistance with funding, all at below market prices (ChileHG, 2006; ChileNorth, 2006; PerulM, 2006; ArgentinaCity, 2006; iDisc, 2003). Some incubators were too new to have space available but were planning to offer space in the future (Bolivia, 2006; ArgentinaCity, 2006) or were operating as virtual incubators (ChileAl, 2006).

\section{Data and Methodology}

The focus of this study was to understand the nature of business incubation activities in a portion of South America. To plan the study, I first attended the CLADEA (Consejo Latinoamericano de Escuelas de Administración) conference of business schools in Santiago, Chile in October of 2005. I conducted exploratory interviews during visits to two incubators at Chilean universities (one public and one private university), and an interview with a venture capital network manager. I was invited to attend the official formation of the Chilelncuba incubator network, and afterwards met with a founder of Santiago's first incubator who was now an official in CORFO, the Chilean government's economic development agency.

The countries selected for the study vary in economic, social and cultural conditions related to business incubation, and in the extent and sophistication of incubation activity. In June, July and August of 2006, I interviewed managers from business incubators, government agencies, non-governmental organizations and entrepreneurship educators in the five countries. Incubators in each country were selected where possible to give a variety of types, locations, sizes, and age (ranging from just founded to very experienced). I also interviewed officials involved in key government incubation financing agencies (CORFO in Chile, SEBRAE and ANPROTEC in Brazil). These agencies were 
particularly helpful in understanding the development of national networks of incubation.

Interviews were usually I.5 to 2 hours long and followed a series of prompts in an emergent style consistent with qualitative research procedures used to develop theory from case data (Eisenhardt, 1989). The managers interviewed were able to direct the conversation into areas that they felt were most important or productive. Important issues raised in earlier interviews were often raised in subsequent interviews to see if experiences and views differed.

Interviews were conducted primarily in English, with some in Spanish and to a lesser extent in Portuguese. I provided simultaneous translation of Spanish and Portuguese responses when needed. To confirm translation accuracy, a former business professor from Chile reviewed and transcribed several interviews with significant amounts of Spanish.
Table I below lists the major interview topics used to structure the interviews. Table 2 lists the number of interviews by country. Appendix I lists the interviews by country with their descriptors. These exploratory interviews were analyzed for the purposes of building a descriptive model. No formal quantitative analyses are presented in this study. Quotes from the interviews appear in italics and are not identified with a specific interview descriptor to protect confidentiality.

Most incubators in the countries in the study were founded in association with universities and were often managed by university faculty (Peru, 2006; Bolivia, 2006; Argentina, 2006; Chile, 2006; Brazil, 2006). The most relevant interviews are cited although the information may have been confirmed in a number of other interviews. Representative quotes are taken from select interviews to illustrate key points of the model. I have edited and where necessary paraphrased interview responses for clarity, brevity and to preserve confidentiality.

\begin{tabular}{|l|}
\hline History and affiliations of the incubator \\
\hline Origins, original sponsors \\
\hline Funding sources for the incubator and incubatees \\
\hline Role of stakeholders in creating and operating the incubator \\
\hline Attitudes toward entrepreneurs and the government \\
\hline Network affiliations of the incubator \\
\hline Private-sector role in incubator \\
\hline Manager and experts employed at the incubator \\
\hline Sources and qualifications of entrepreneurs \\
\hline Programs for developing incubatee firms \\
\hline Degree of specialization by the incubator \\
\hline Techniques used by the incubator \\
\hline Services and resources available for incubatees \\
\hline Sources of revenue for the incubator \\
\hline Long-term development objectives for the incubator \\
\hline
\end{tabular}

Table I. Key incubator interview prompts 


\begin{tabular}{|c|c|c|c|c|c|}
\hline & $\begin{array}{l}\text { Incubators } \\
\text { interviewed }\end{array}$ & $\begin{array}{l}\text { Educators } \\
\text { interviewed }\end{array}$ & & $\begin{array}{l}\text { Sponsors or } \\
\text { agencies } \\
\text { interviewed }\end{array}$ & $\begin{array}{l}\text { Estimated } \\
\text { Number of } \\
\text { incubators } \\
\text { in 2006* }\end{array}$ \\
\hline Argentina & 2 & & 1 & 1 & 10 to 15 \\
\hline Bolivia & I & & 0 & 0 & 2 \\
\hline Brazil & 10 & & 0 & 2 & $299+* *$ \\
\hline Chile & 5 & & 1 & $\mathrm{I}$ & 21 \\
\hline Peru & I & & 2 & 1 & 2 to 5 \\
\hline Total & 19 & & 4 & 4 & \\
\hline
\end{tabular}

** Estimates based on internal documents and interview comments (Brazil CMP, 2006; Brazil SEB, 2006).

Table 2. Interviews and estimated number of incubators by country

The analysis that follows describes a model of the development of business incubation in emerging markets. Data for the model came from experts from five different countries with varied levels of incubation practice. The model integrates observations of incubation practices with organizational learning, diffusion of innovation, institutional and national systems of innovation theories. I illustrate the model with observations and quotes from the interview data.

\section{The Model}

I propose that incubation systems in emerging markets evolved in stages driven by their clients' needs for services and the choices of their governments for economic development. Nelson and Winter (1982) identified routines as the key to how economies evolve. In the context of business incubation systems, pioneering incubators were founded using routines imported from foreign NGOs. Using established routines from organizations with incubation experience served to give these nascent incubators legitimacy and helped overcome initial skepticism by local sponsors (Dimaggio and Powell, 1983) and over time the incubators adapted those routines to serve local entrepreneurs.

The three stage of the model are the pioneering stage, the operating stage and the advanced stage. Below I explain and illustrate each of the three stages of incubator development. I describe issues identified by incubator professionals that influenced the development of the incubators routines and capabilities. Each section of the model also discusses the co-evolutionary development of incubator networks. Incubators form national networks due to a number of factors:

- Budgetary pressures pushed each incubator to show efficacy and by use legitimate incubation practices.

- Networks acted as conduits to pass economic development aid from the government to incubators and on to start-up firms.

- Sponsors' required assurance that their resources were being used well by incubators.

- Sharing services across incubators helped efficiency.

- Incubator networks lobbied for government reforms and monitored incubator quality.

\section{Pioneering Stage}

Several incubators interviewed were founded in conjunction with international development change agents (such as infodev, a World Bank incubation sponsor). Once established in a country, the pioneering incubators acted as broadcast sources (Dimaggio and Powell, 1983; Miner and Haunschild, 1995) further disseminating incubation practices. 
NGOs seeded new incubators into a country in order to promote incubation as a way to improve economic development, create employment and increase innovation in emerging markets (iDisc, 2003). In this study, NGO's sponsored new incubators in Bolivia and Peru. Years earlier a similar process had founded early incubators in Brazil and Chile. Universities sponsored most of the incubators in this study as a way to demonstrate support for government development efforts, gain funding, and to fulfill their mission to improve national innovative capacity (PeruUniv, 2006; ChileHG; CORFO, 2005).

Copy proven incubation techniques to gain legitimacy. The pioneering stage for incubators is characterized by the incubator attempting to gain support from its environment. Business incubation is an innovation. Innovations diffuse into a market more readily if they have been shown to provide tangible benefits, especially economic advantage over existing technologies (Griliches, 1957; Rogers, 1995). Economic advantage is difficult to show for pioneering-stage incubators given that it may take over two years for the first incubatee firm to enter the marketplace.

According to institutional theory (Dimaggio and Powell, 1983; March, 198I) one way to gain legitimacy is to copy the routines of stakeholders or leading organizations in the society. Another key to legitimacy is to be effective in achieving valued outcomes. The new incubators used proven incubation techniques imported from experienced development agencies to provide effective incubation. Change agents like infodev provided a track record in other countries that incubation was an appropriate technology for emerging markets.

Managers of pioneering incubators emphasized that successful incubation began with the recruiting of clients that are willing to learn, can take direction, and have a business idea with some competitive advantage (PerulM, 2006; ChileAN, 2006; ChileAl, 2006; ArgentinaDES, 2006). Pioneering incubators worked hard at avoiding failures and creating successes so that the incubator justified being funded (Bolivia, 2006; PerulM, 2006; ChileNorth; 2006). For this reason, pioneering incubators copied the most effective incubation routines used by more experienced

ISSN: 07I8-2724. (http://www.jotmi.org )

Journal of Technology Management \& Innovation (C) Universidad Alberto Hurtado, Facultad de Economía y Negocios incubators and NGOs (e. g. using business plan contests to attract potential incubatees).

Focus on overcoming cultural biases regarding entrepreneurs. Cultural attitudes affect entrepreneurs' willingness to incubate and the image of entrepreneurs in society. How entrepreneurship is viewed in a society is an important issue for pioneering incubators. According to Rogers (1995, Pp. 127-128 citing Bordenave, (1976) regarding new technology being diffused to Latin America) the technology should be "appropriate, well proven and adequate for the stage of socioeconomic development of the nation." Incubation was seen by some educators and foundations as an answer to economic development but it was controversial due to a history of exploitation by business owners. Several university entrepreneurship educators in Peru noted that microentrepreneurs were admired but owners of large businesses were regarded with suspicion and suppressed entrepreneurs' desires to participate in incubation. They attributed this reluctance to years of corrupt governments, domination by foreign companies, and resentment of others' success (PeruPRV, 2006; Bolivia, 2006).

"...we had the same problem with older firms with old entrepreneurs, people who are now chairman of national, local firms...they are devils! To say that you are entrepreneurs here is not good and that's culture. That's what we want to change to say that entrepreneurship is good, to say that you are going to get entrepreneurs, that is good, not bad."

A Bolivian foundation representative summarized antientrepreneurial attitudes this way:

“...our president, our ministers, all of them are concerned about political issues...they don't know what [an] entrepreneur is, they don't like entrepreneurs because [of] what they think about entrepreneurs, they think about the old business man that has exploited all the people in Bolivia, and that as well [is] a reality here."

Finally, activities in Brazil's social incubators (targeted at alleviating poverty and solving social problems) (BrazilCMPSOC, 2006) as well as rural incubators in Brazil (BrazilMG, 2006) and smaller cities in Chile 
(ChileNorth, 2006) were similar to the pioneering stage incubators in Peru. These social and rural incubators were isolated, had difficult times recruiting entrepreneurs with good business ideas, or faced strong stigmas associated with business owners and capitalism (social incubators) in spite of being members of sophisticated incubation networks.

Overcoming low aspiration levels of entrepreneurs of necessity. Suspicious attitudes toward entrepreneurs and lack of bankruptcy protections all increased the risks associated with starting a new business. The net effect of these cultural and structural issues was to suppress the aspiration levels of potential entrepreneurs away from ambitious high profile, high growth businesses that incubators seek to serve. Interestingly, these suspicions did not suppress the widespread desire to start micro-businesses. The micro-banks in Bolivia and Peru resulted in many willing micro-entrepreneurs, a mixed blessing for incubators:

"And that's the reality of a poor country here in Latin America...I put my own business because I want to survive. I can't get a job so I have to survive and that's the production of the poor sector of our economy, why because you see your neighbor is working now, selling some chips and snacks and say, oh, that could be a good job to survive...Today I sell chips; tomorrow I'm going to sell some chewing gum and those things."

"...they can go to the micro finance institutions and get a two hundred dollar loan without a guarantee, only signing the contract. l'm going to pay the interest rate of $28 \%$ but you know I can go to buy the chips for 10 cents and sell them for 20 cents. I have 100\%, I can afford this."

Incubator managers referred to the owners of these micro-businesses as "entrepreneurs of necessity" because the created their businesses to survive an economy that had high unemployment. Entrepreneurs' of necessity were regarded as mixed blessings because they only employed one person, were often "unofficial" (unregistered so they paid no taxes) but they did help reduce poverty. The net effect of these cultural conditions was that entrepreneurs lowered their aspiration levels, resisted growing beyond soleproprietorships, and avoided "official" agencies like incubators.

Unfortunately, micro-businesses also competed with the pioneer incubators for government financing and consumed the incubators' scarce counseling resources. One incubator consultant noted that by helping unregistered micro-entrepreneurs who had no desire to grow or to become official, he was using government resources to help entrepreneurs of necessity avoid paying taxes, thereby jeopardizing the incubator's reputation (PeruPRV, 2006). However, to ignore these entrepreneurs risked alienating the public against the university and the incubator. To avoid this, incubators put on public education programs for the city government that helped train all entrepreneurs (PeruPRV, 2006).

Confronted by the difficulty of overcoming anti-owner biases and low aspiration levels, two managers from pioneering incubators expressed almost missionary-like determination to help entrepreneurs succeed:

"You have to compete with Brazilian companies; you have to compete with Chilean companies; that is the hard work. And we are trying to put this in the minds of the entrepreneurs. That is hard work because you have to work a lot changing our culture... but you have to do it."

“We hope that we're not going to have lots of changes [in government policy]... we have to work because the people will not wait, the people have to work, the people have to export, the people have to eat...so we have to not wait... we are still working."

To raise entrepreneurs' aspiration levels, pioneering incubators provided high levels of pre-incubation services hoping to enable entrepreneurs to grow their businesses and create more jobs. Bolivian and Peruvian incubators taught entrepreneurs basic business planning, management principles, and guided entrepreneurs through the government registration process. The incubators also worked to find selling opportunities for the new ventures to help them be able to expand. 
Pioneering stage networks: Precursors to incubator network formation. Networks facilitate learning from others' experiences and provide a basis for building political support to obtain resources and advance regulatory changes. In Peru, Bolivia and Argentina there were no formal national incubation networks. Instead, incubators worked in isolation in part due to geographic separation (e.g. The incubators in $\mathrm{La} \mathrm{Paz}$ and Santa Cruz in Bolivia knew very little about each other). Below I discuss the varied early network formation activities in Peru, Bolivia and Argentina.

In the pioneering stage of incubation, networks do not exist or are relatively unimportant to the operation of the incubators. The incubators were still trying to figure out how to incubate new businesses and how to secure resources to pay for their efforts (PerulM, 2006; Bolivia, 2006). For example, the Bolivian incubation and economic development experts had discussed the potential formation of a network in the future but it seemed to be a secondary concern given the immediate challenges of starting their incubator (Bolivia, 2006).

However, as incubation gained more structure and was seen as more legitimate, it attracted more entrepreneurs and more sponsorship from government and other agencies (CORFO, 2005). Pioneering incubators in countries that do not have networked incubator systems lose the benefit from the learning that can occur from knowledge spillovers (Cohen and Levinthal, 1990) as experiences and ideas flow across incubators. Capturing knowledge spillovers is one reason incubators co-locate their firms, so that the clients can interact and build synergies across clients. A network can capture these same synergies and export them to many incubators but if there is no network those experiences do not diffuse throughout the national incubation system.

In the pioneering stage, incubators begin planning how to form networks. For example, Peru could have copied Chile's network structure. Peruvian faculty and incubator managers interviewed said that they admired Chile's network which had been formed in October, 2005. However, both Peruvian and Bolivian incubator managers would not solicit technical assistance from Chile due to the concern that their governments would punish them. Their fear stemmed from recurring border disputes with Chile resulting from a war fought with Chile in the previous century. Instead, pioneering stage incubators in Peru and Bolivia relied on learning from international NGOs such as infodev as well as Colombian and Brazilian incubators.

Argentina was a different case. Incubators had significant funding partly as a political response to the unemployment caused by the devaluation of its currency several years earlier (ArgentinaDES, 2006). Formal networks were not initiated due in part to rivalries between the national, state, and city of Buenos Aires governments. In spite of the complex environment, the need to coordinate activities and the driving spirit of incubation managers and economic development professionals led to an emergent and informal grassroots economic development and incubation movement. The group had begun to meet periodically several months before my interviews. The group was formalizing their meetings and planning to become an official trade group that would serve as a nucleus to help guide government development policy (ArgentinaUniv, 2006).

\section{Operating Stage}

During this stage, the incubator builds on its track record of helping entrepreneurs and selects entrepreneurs with higher ambitions. Although some pre-incubation activities are always needed, operating stage incubators focus on helping clients form strong venture management teams (ChileAl, 2006), improving their products, and finding funding for expanded operations. As their resource commitment to the incubatee grows, incubators introduce performance measures to hold clients accountable. Below I explain the operating stage activities of incubators observed in this study.

More aggressive screening for higher growth businesses resulted in incubators with more ambitious clients. To serve these clients, operating stage incubators began to develop idiosyncratic capabilities. For example, two Chilean incubators developed significant capabilities in working with technology innovations that required engineering and intellectual property services. 
While pioneering incubators focused on developing the business concept and initial entry, operating incubators focused on commercialization and fostering growth. Here are two descriptions of this process:

"And here are the capacities that we have for example: project area that basically helps entrepreneurs to get government grants warranty... marketing or technological of the unit, ...patenting, and also looking for associates to do the licensing."

“...beginning commercializing, that's enough for the company and after that is ok, the production scaling that you need to grow the company and start to sell even more than you're doing it in a very serious stage... we can say that this is a very typical curve."

Screening resulted in more ambitious ventures that needed more resources to reach commercialization and thereby creating higher demand funding for incubatees. Once incubation has demonstrated success, governments desire to magnify the incubators' benefits to the economy and introduce programs to fund the early operation of the business. Emerging markets are often short of venture capital and investors are unwilling to take risks on unknown entrepreneurs. The incubator and its sponsors use their reputations and relationships to advance their incubatees. Government development agencies introduce funding programs. For example, CORFO developed a clever risk-sharing program for seed capital that mixed private and public funds for prototyping and early commercialization. Incubators received funding to help pay for consulting services but had to screen applicants for strong growth potential.

In the operating stage, incubators had more at stake with each client so they developed improved screening methods and criteria. A strong selection process improved the chances that the venture would be competitive. A university incubator with a technology focus described their selection routine below:

"...so now they are looking for projects that they can transform into a business. That's the key...they are looking at the whole process of tech transfer as they find these ideas that they want to transform into businesses, often they find them with their internal research people and they develop them into formal businesses."

Measures of incubator and incubatee success. Operational incubators develop capabilities that address the key issues of their incubatee firms and their sponsors. As the firms at this level are screened more vigorously for competitive advantage and growth potential, the incubators have to provide more assistance with funding, production, marketing and intellectual property protection. Funders' expectations will lead to the development of measures of incubator performance.

Key outcomes for pioneering incubators included the number of firms in pre-incubation, the number of business plans completed, and applications submitted to sponsors for start-up funding (ChileNorth, 2006). In the operating stage the incubatee is to have gone beyond a prototype to selling on a regular basis and generating funds to help pay for some incubation services. An operating stage incubator manager described two key measures he used to judge incubator success:

"one is number of companies [graduated from the incubator]; another one is have we been at least even with our resources? We did not lose, or giving more money, we're even."

Operating stage incubators did not have the "antientrepreneur" cultural issues that pioneering incubators confronted. However, lack of bankruptcy laws and the heavy social stigma of declaring bankruptcy increasingly impacted operating stage incubators in their dealings with potential incubatees. Incubators worked actively to avoid or prevent bankruptcy by screening ventures and owners more closely and using higher metrics for expected revenues in deciding which firms to incubate. Bankrupt clients hurt the incubator's reputation as well as that of its sponsors (ArgentinaUniv, 2006). Entrepreneurs invested significant personal resources into the startups and worried that they might go bankrupt which could limit their future career prospects. For example, consider this response to the question: Is there a bankruptcy procedure? 
“No...it's not regulated. You can't say now l'm back to nothing...we don't have that legal procedure for that. For example, it's culture as well because in the States, I think when you say ok, I have problem and I go bankrupt, you have earned some experiences and you are not going to do the same. And the system see you that ok, you are not going to do the same, you are going to have another opportunity but here, you've got a bankrupt...You are a devil, you don't exist."

Operating stage network capabilities. Prior to forming a network, specialized capabilities such as expertise in intellectual property or in certain forms of engineering were not used by other incubators except on an occasional basis. (ChileDCT, 2006; BrazilCMP, 2006). Incubators derived value from serving their clients and responding to their needs. Pressures to spread these services were applied by government and other sponsors in part through the use of budget allocations.

As incubation infrastructure grew, the incubators and those supporting them developed coordinating mechanisms. To satisfy their government and institutional sponsors (usually universities) incubators spread expenses across as many incubatees as possible. Incubators with unique capabilities provided those services to other incubators informally in the operating stage. However, the cooperative contacts with other incubators (Etzkowitz, et al., 2005) (BrazilANP, 2006; BrazilCMP, 2006) helped reinforce the value of formalized exchange processes in the incubation networks.

In the operating stage, incubation networks are negotiated and formed. Chilelncuba's formation was a good example, originating after a period of independent incubation. Chile's incubators wanted to band together to negotiate with the government for better venture funding and to share resources (CORFO, 2005) (ChileHG, 2006). Some incubators in the system had advanced capabilities and could bring considerable knowledge to the other incubators. However, there was still an atmosphere of rivalry and competition among the incubator members making performance measures a potential future problem (ChileAI, 2006; CORFO, 2005; ChileNorth, 2006).

\section{Advanced Stage}

Advanced stage incubators engage more intensely and more often in a number of issues that are noticeably different than confronted in earlier stages. The capabilities of advanced incubators must serve clients that are technically sophisticated and have growth potential. Development of capabilities was a function of both individual incubator goals and skills as well as the co-evolution of the capabilities in the incubator network and government support systems for investment (Nelson, 1993).

In the advanced stage, incubators are still focused on finding firms to incubate however the expectations of the firm and the entrepreneur by the incubator are more demanding. Eligible firms must pass significant hurdles in terms of having a clear competitive advantage, potential for securing intellectual property protection, willingness to form a strong venture team, and eligibility to obtain initial capital investment often through an incubator network administered funding initiative. One incubator manager described it this way:

“...we are a technology based incubator...it's technology in the very wide sense of the word. What I mean is we are basically focusing on innovation. It can be innovation in technology, or in business models but the most important thing is the business must have some sustainable competitive advantages... Intellectual properties is not the only requirement, we have received some projects that don't have intellectual properties protection but have...several resources that create this entry barrier..."

A number of advanced incubators took equity positions in exchange for their incubation services. Advanced incubators with equity stakes in ventures were effectively managing an investment portfolio of formerly incubated companies. This was a choice made by the entrepreneur and the incubator in part to ensure a continuing relationship with the incubator after the firm graduates to independence (ChileDCT, 2006; BrazilBIO, 2006; ChileAI, 2006). 
"We had some examples [of start-ups] in different industries, not a very particular focus but all of these companies involve engineering knowledge/services, and they started as different departments and then...they were spun out and went independently out into the market and the incubator has an equity ownership in the companies."

Advanced incubators usually had incubated more firms and larger firms. Their staff were also more specialized in order to provide more sophisticated services and to manage their government and incubator network relationships (usually done by the incubator manager in operating incubators). Finding investment capital and managing government grants demanded much more effort than during the operating stage. One incubator manager described their staffing as follows:

"Incubation is [Name]who takes the lead in the typical work of incubation: legal support, managing the process of incubation and investment. I take the lead in finance investment, it's when they need some private fundings. What we try to do is to find a strategy to create the biggest company as possible before involving outside investors or angel networks."

Specialization of incubators. In advanced systems, specialized incubators emerge to serve a particular industry, technology, sponsoring organization or delivery of a particular service. For example, an incubator in Brazil focused exclusively on biotechnology, another focused on innovations in the advanced electronics industry and yet another focused on faculty innovations from a large university. In one software incubator, $80 \%$ of its clients were faculty and students from its sponsoring university (BrazilSoftl, 2006). Further specialization in incubation occurred when the government created funding for "social" incubators targeted to alleviate poverty in marginalized populations through formation of cooperatives and collectives (Etzkowitz, et al., 2006; BrazilAN, 2006; BrazilCMPSOC, 2006).

Even the largest incubators often do not have enough incubatees to justify maintaining special capabilities for their incubator alone. Sharing specialized services set off internal competition in national networks between incubators wanting to secure preferred treatment from the funding agencies. Special skills could help their incubators gain importance in the networks and ensure their incubator's ability to survive periodic government funding cuts. Shared services frequently included intellectual property law (patenting and licensing), scientific testing and analysis, and engineering services. Incubators actively lobbied the network administrators to be service providers to network members (BrazilBIO, 2006; BrazilCMP, 2006; CORFO, 2006; ChileHG, 2006).

"we don't have enough of the kind of products to support our licensing technology office itself for each university...so there are several universities bidding...to do licensing and we are considered as one of the alternatives [i.e. possible choices to do the licensing]."

Advanced stage incubator network capabilities. In the advanced stage, incubators are facing higher demands from their more sophisticated incubatees and must either develop capabilities or find them elsewhere. Networks institutionalize collaboration between incubators by establishing who will specialize and how they will be compensated. An increased demand for funding has the network coordinating the development of new funding initiatives, and negotiating with government agencies and international funders (BrazilSEB, 2006). Finally, the networks face increased scrutiny from their regulators resulting in development of performance measures. These measures encourage incubator efficiency and effectiveness. The network uses its coercive strength (ability to withhold resources) to impose these measures on the incubators. Below are my observations of advanced stage networks:

Networks allow for the new incubators to benefit from the recycling of knowledge from the pioneering incubators in the form of routines, technology, and processes (Nelson and Winter, 1982; Teece, 1986). In general, transfer of knowledge can occur through indirect observation of spillovers (Cohen and Levinthal, 1990), the movement of employees (Robinson and Miner, 1996), or imitation of practices of other organizations (Dimaggio and Powell, 1983). In the advanced stage knowledge flows in part through 
the systematic transfer of personnel for temporary or permanent assignments, including service to the network itself in centralized networks (BrazilSEB, 2006). In one Brazilian network, incubator managers were required to move to different incubators every three years (assuming the manager effective enough to be wanted by another incubator) (BrazilNetwork, 2006; BrazilMG, 2006).

The national incubator networks acted as coordinating mechanisms to spread effective incubation practices and also helped the incubators magnify their influence on national policies. For example, Chilelncuba coordinated the exchange of best practices across its members (CORFO, 2005). In Brazil, ANPROTEC functioned as a trade group for incubators and sponsored educational conferences for incubator managers.

During this stage, governments introduced funding programs focused on firms that were commercializing their products and services. Advanced incubators used mixed funding sources (private sector, government and foundations) (BrazilCMP, 2006; BrazilSEB, 2006; Etzkowitz, et al, 2005) to support their operations. Networks used calls for proposals to induce incubators to put forward clients for investment to increase "deal flow" (i.e. the creation of new ventures available for investment). Low deal flow discouraged private sector venture financing of incubatee firms because there were few lucrative firms that would support venture financing (BrazilANP, 2006; BrazilSEB, 2006). Chile had a two-stage investment program providing early business planning and prototyping support, and later support for expansion and commercialization (CORFO, 2006). An advanced incubator in Chile was spearheading the creation of an angel investor network to build investment in incubatees (ChileAN, 2005; ChileAl, 2006).

Introduction of performance measures at the network level. Resistance to network formation can be significant. The incubator fears losing control to the network managers. Incubator performance evaluations by the network began as a way to spread best practices and establish milestones for incubatee and incubator performance (BrazilNetwork, 2006). These performance measures diffused by having respected incubator managers develop and promote (Rogers, 1995) the new measures at annual incubation conferences (BrazilCMP, 2006). For example, the Brazilian network counted the number of incubatees and graduated firms in its performance measures. Some incubators objected to these measures because they did not value quality (high growth ventures with large sales) but instead valued quantity (small low growth businesses). The measures were changed (BrazilNetwork, 2006; BrazilANP, 2006) By linking funding to incubator performance on these measures, the networks effectively coerced incubators to mimic network policies (Dimaggio and Powell, 1983). Network managers predicted that resistance to evaluations would fade as the incubators began to take them for granted (March, 1981).

Brazil required reporting of performance indicators (e.g. incubatee gross sales receipts, tax revenue from those sales, and the number of jobs created by incubatees) and used incentives to reward strong performance (BrazilCIE, 2006). Regional and national networks used performance data to show that their incubators were returning value-added for their countries. Comparability of performance across networks increased pressures to clone the best performing incubators and trim the worst to save costs. Not surprisingly, incubator managers welcomed the use of indicators if their incubator performed well but feared them if the incubator was a "poor" performer (BrazilSOC, 2006; BrazilNetwork, 2006).

\section{Conclusion}

Business incubation practices in emerging market nations vary in the extent of their diffusion as well as the variety of incubators that are operating in each country. By performing interviews in several countries that had differing levels of incubation capabilities I was able to see the differences and similarities across incubators as well as the national networks of business incubation that were forming or had formed in those countries.

The study proposes an empirical model that integrates observed business incubation practices with diffusion of innovation, organizational learning and institutional theories. The model addresses the specific stages of 
evolutionary development of the diffusion of business incubation and the development of national incubation networks. The stages are illustrated with examples of relevant practices or conditions from each of the five countries, Argentina, Bolivia, Brazil, Chile and Peru. Table 3 below summarizes key observations.

\begin{tabular}{|c|c|}
\hline Incubation Characteristics & Network Characteristics \\
\hline \multicolumn{2}{|l|}{ Bolivia (early pioneering stage) } \\
\hline - Pioneering incubators just developing & - Idea of having a network discussed \\
\hline - Pre-incubation focus & - No coordination of incubation policy \\
\hline - Focus on encouraging entrepreneurs & - Little effort to exchange services or learning \\
\hline - Low level of government support & \\
\hline \multicolumn{2}{|l|}{ Peru (pioneering in transition to operating stage) } \\
\hline $\begin{array}{l}\text { - Pioneering incubators transitioning to operating } \\
\text { level }\end{array}$ & - Initial steps for network formation \\
\hline - Pre-incubation focus & - Incubators collaborating and meeting \\
\hline $\begin{array}{l}\text { - Entrepreneurs of necessity competing for } \\
\text { resources }\end{array}$ & - No formal structure but working on plan \\
\hline - Government supportive but low funding & \\
\hline \multicolumn{2}{|l|}{ Argentina (mixed pioneer loperating stage) } \\
\hline - Incubators at all three levels & - Informal incubation meetings - no network \\
\hline - Government development policy fragmented & $\begin{array}{l}\text { - Grassroots network movement emerging from } \\
\text { economic development meetings }\end{array}$ \\
\hline $\begin{array}{l}\text { - Incubators screen out entrepreneurs of necessity } \\
\text { in favor of higher growth clients }\end{array}$ & $\begin{array}{l}\text { - Government struggling with complex rules } \\
\text { seems unable to organize networks }\end{array}$ \\
\hline \multicolumn{2}{|l|}{ Chile (operating moving to advanced) } \\
\hline - Most incubators at operating level & - Newly formed network \\
\hline - Newest incubators are at pioneer level & - Incubators created the network \\
\hline - Government sponsored funding for incubatees & - Funding programs aid incubators and clients \\
\hline & - Angel investment network newly formed \\
\hline \multicolumn{2}{|l|}{ Brazil (advanced with multiple networks) } \\
\hline - Mixed levels with most at operating level & - Top-down control of incubators \\
\hline - Advanced incubators specialized by industry & - Networks spread best practices \\
\hline $\begin{array}{l}\text { - Sophisticated services offered by advanced } \\
\text { incubators to others }\end{array}$ & $\begin{array}{l}\text { - Funding programs administered through } \\
\text { networks }\end{array}$ \\
\hline $\begin{array}{l}\text { - Blended government and private financing } \\
\text { program }\end{array}$ & $\begin{array}{l}\text { - Multiple networks formed to serve general } \\
\text { incubators, industry specific incubators }\end{array}$ \\
\hline
\end{tabular}

Table 3. Network descriptions by country

The results of this study indicate that there is a progression for the development of incubation practices in emerging markets, but it is a varied and complex progression. Cultural factors influence the acceptance of incubation by potential entrepreneurs. Early specialization by certain incubators shapes the incubation networks' capabilities to assist entrepreneurs. As networks develop, incubators must demonstrate their ability to graduate successful firms into the market. 
Incubation networks evolve from the "bottom-up" to serve the needs of the incubators. As the network matures and the incubators need more resources to provide their clients extensive financial and technical support, the national government provides added funding and partnerships with venture capital providers emerge. In turn, government sponsors and investors demand more accountability and demonstrable economic development outcomes such as increased employment, tax revenues, etc. Because of their increasing investment (both financial and political) in incubator success, the government exerts stronger influence over the incubator network and the network becomes a more top-down regulator of incubator activity.

\section{References}

BORDENAVE, J. (1976) Communication of Agricultural Innovations in Latin America. Communication Research, 3(2), |35-|54.

COHEN, W., Levinthal, D. (1990). Absorptive capacity: A new perspective on learning and innovation. Administrative Science Quarterly, 35, 128-152.

CANTWELL, J., Dunning, J., Lundan, S. (2010). An evolutionary approach to understanding international business activity: The co-evolution of MNEs and the institutional environment. Journal of International Business Studies, 4 I (4), 567-586.

DIMAGGIO, P., Powell, W. (1983). The iron cage revisited: Institutional isomorphism and collective rationality in organizational fields. American Sociological Review, 48, I47-160.

ETZKOWITZ, H., Mello, J., Almeida, M. (2005). Towards "meta-innovation" in Brazil: The evolution of the incubator and the emergence of a triple helix. Research Policy, 34, 4||$-424$.

GRILICHES, Z. (1957). Hybrid corn: An exploration in the economics of technological change. Econometrica, 25(4), 50I-522.

HACKETT, S., Dilts, D. (2004). A systematic review of business incubation research. Journal of Technology Transfer, $29(1), 55-82$.
iDISC Papers. (2003, October). Infodev/iDISC Regional workshop for business incubators in Latin America and the Carribean. Brasilia.

LEVINTHAL, D., March, J. (198I). A model of adaptive organizational search. Journal of Economic Behavior and Organization, 2, 307-333.

MARCH J. (198I) Decisions in organizations and theories of choice. In: A. Van de Ven and W. Joyce (Eds.) Perspectives on organization design and behavior, 205-244, Wiley, New York.

MINER, A., Haunschild, P. (1995). Population level learning. In L.L. Cummings, B.M. Staw (Eds.), Research in Organizational Behavior, 17, II5-166. JAI Press, Greenwich, CT.

NELSON, R. (Ed.). (1993). National Innovation Systems: A Comparative Analysis. Oxford University Press, New York.

NELSON, R., Winter, S. (1982). An evolutionary theory of economic change. Belknap Press of Harvard University Press, Cambridge, Mass.

ROBINSON, D., Miner, A. (1996). Careers change as organizations learn. In: M. Arthur, D. Rousseau (Eds.), The Boundaryless Career: a new employment principle for a new organizational era. Oxford University Press, New York.

ROGERS, E. (1995). Diffusion of Innovation (4th ed.). The Free Press, New York.

TEECE, D. (1986). Profiting from technological innovation: Implications for integration, collaboration, licensing and public policy. Research Policy, 15, 285-305. 


\section{Appendix I}

Interviews were conducted in October, 2005 and June through August 2006 and are cited in parentheses using a Country name, a descriptor and the year of the interview. Specific names are not used to ensure the anonymity of the interviewees.

I) ArgentinaCity, Incubator Manager(s). July, 2006.

2) ArgentinaDES, Incubator Manager(s). July, 2006.

3) ArgentinaEND, Private Venture Capital Foundation. July, 2006.

4) ArgentinaUniv., University Entrepreneurship Educator(s). July, 2006

5) Bolivia, Incubator Manager(s) and private foundation. June, 2006.

6) BrazilANP, Incubator Trade Association Official(s). July/August, 2006.

7) BrazilCDT, Incubator Manager(s). July/August, 2006.

8) BrazilBIO, Incubator Manager(s). July/August, 2006.

9) BrazilNetwork, Incubator Network Manager(s). July/August, 2006.

10) BrazilMG, Incubator Managers. July/August, 2006.

II) BrazilSEB, Brazilian Economic Development Official(s). July/August, 2006.

12) BrazilCMP, University Incubator, Official(s). July/August, 2006.

13) BrazilCMPSOC, Social Incubator Manager(s). July/August, 2006.

14) BrazilSoft I, Software Incubator Manager(s). July/August, 2006.

15) BrazilBRSSOC, Social Incubator Manager(s) (public university affiliation). July/August, 2006.

16) BrazilRF SOC, Social Incubator Manager (with religious affiliation). July/August, 2006.

17) ChileUC, University incubator, Official(s). June, 2006.

18) ChileDCT, University Incubator (engineering oriented) Official(s). June, 2006.

19) ChileAl, University Entrepreneurship Professor, Official(s). June, 2006.

20) ChileHG, Incubator Manager(s). June, 2006.

21) ChileAN, Incubator Manager(s). October 2005 and June, 2006.

22) ChileNorth, Incubator Manager(s). June, 2006.

23) CORFO, Economic Development Official(s). October, 2005.

24) CORFO, Economic Development Official(s). June, 2006.

25) PerulM, Incubator Manager(s). June, 2006.

26) PeruUniv., Entrepreneurship Educator(s). June, 2006.

27) PeruPRV, University Entpreneurship Educators (private university). June, 2006. 